Kinestetik : Jurnal Ilmiah Pendidikan Jasmani 5 (3) (2021)

Kinestetik : Jurnal Ilmiah Pendidikan Jasmani

https://ejournal.unib.ac.id/index.php/kinestetik/index

DOI : 10.33369/jk.v5i3.17399

\title{
ANTHROPOMETRIC AND BIOMOTOR PROFILE ANALYSIS OF WATER SKI AND WAKEBOARD ATHLETES OF DKI JAKARTA PROVINCE
}

\author{
Uzizatun Maslikah $^{1 *}$, Masnur Ali ${ }^{2}$, Endy Safadilla ${ }^{3}$, Haris Nugroho ${ }^{4}$, Eko Sudarmanto ${ }^{5}$ \\ ${ }^{13}$ State University of Jakarta: Sports Coaching, Faculty of Sport Science, Universitas Negeri \\ Jakarta, Jakarta, Indonesia \\ ${ }^{2}$ State University of Jakarta: Sports Recreation, Faculty of Sport Science, Universitas Negeri \\ Jakarta, Jakarta, Indonesia \\ ${ }^{4}$ Sebelas Maret University: Sports Training Education, Faculty of Sports, Universitas Sebelas \\ Maret, Surakarta, Indonesia \\ ${ }^{5}$ Muhammadiyah University of Surakarta: Sports Education, Teacher Training and Education \\ Faculty, Universitas Muhammadiyah Surakarta, Surakarta, Indonesia
}

\section{Article Info}

Article History :

Received : August 2021

Revised : September 2021

Accepted : September 2021

Available online : September 2021

Keywords:

Anthropometry, Biomotor, Water Ski, Wakeboard

\section{Abstract}

The purpose of this study was to analyze the anthropometric and biomotor profiles of water skiers and wakeboard athletes in DKI Jakarta Province. The descriptive method uses a quantitative research type approach. The population and sample in this study were water skiers and wakeboard athletes as many as 25 male athletes. Data collection techniques used tests and measurements: (i) weight scales to measure body weight. bodyweight is measured using measuring body weight with a unit of kilograms; (ii) physical condition test; bend using the sit and reach test; core stability, namely athletes perform with 12 levels with perfect attitude, level 1 to level 12 where levels 1 and 12 for 30 seconds, level 2 to level 10 for 15 seconds, sit-ups and push-ups test athletes perform tests for 1 minute, limb explosive power did a standing long jump test, and endurance did a Multi-Stage Fitness Test (MFT). Data analysis uses quantitative descriptive analysis techniques, overall data analysis uses Microsoft Excel 2019. The results of this study can be concluded: anthropometry and physical condition are one of the important factors in determining athlete achievement, without exception for the DKI Jakarta Water Ski and Wakeboard Athletes.
Corresponding address : Kampus B UNJ, J1. Pemuda No. 10,

Rawamangun, Jakarta Timur

*Corresponding email : uzizatunmaslikah@unj.ac.id
ISSN 2685-6514 (Online)

ISSN 2477-331X (Print) 


\section{INTRODUCTION}

The development of national sports is one of the efforts to improve the quality of human resources. In this regard, national sports have a role to maintain and improve the health and fitness of the community, shape the character and personality of the nation by instilling the value of sportsmanship, discipline, strengthening and fostering friendship between nations, and strengthening the unity and unity of the nation (UU No 3 Tahun 2005). Moreover, sports can lift the dignity, dignity, and honor of the nation through sporting achievements at the provincial, national and international levels. In that context, with the empowerment of sports, the sense of nationalism and national identity becomes clearer.

Conducting activities regularly and programmatically through sports achievements able to lift the dignity, dignity, and honor of the nation through sporting achievements at the provincial, national and international levels (Fachrezzy et al., 2020; Hermawan et al., 2021; Jariono \& Subekti, 2020). In that context, with the empowerment of sports, the sense of nationalism and national identity becomes clearer. Sports activities cannot be separated from human life, in exercising each individual has a different purpose, some aim for achievement, physical freshness, and recreation (UU RI, 2005).

A reality there are four basic human goals to do sports activities today. First, humans do their activities for recreation, namely humans who do sports just to fill their leisure time, done full of joy, so that it is done casually and informally, both places, facilities, and regulations. Second, humans who do sports activities for educational purposes, such as school children who are fostered by sports teachers. Formal activities, the goal is to achieve the national education goal through sports activities arranged through certain curricula. Third, humans do sports activities to achieve a certain level of physical freshness. Fourth, humans perform certain activities to achieve optimal achievement. Sports that aim to achieve optimal achievement require good and regular exercise.

The modern training principles of each sport require specificity. There are four kinds of completeness that need to be possessed if one will achieve an optimal achievement. Proper physical condition plays an important role in improving the appearance of athletes. Improving the physical condition of athletes aims to make physical abilities excellent (T. O. Bompa \& Buzzichelli, 2018).

Physical condition plays an important role in achieving the maximum achievement of an athlete to achieve maximum achievement, and even a very basic ability to achieve an achievement (Nugroho et al., 2021; Ohayon, 2005). Therefore, an athlete cannot step up to the top of his achievement when it is not supported by good physical condition. Athletes don't need all the components of their physical condition. Athletes only need a few components of the physical condition according to the characteristics of the sport they follow, namely an athlete must have basic physical components, namely: endurance, strength, speed, and flexibility or coordination (T. O. Bompa \& Buzzichelli, 2018). This research aims to find out about the anthropometric and biomotor profiles of water ski athletes and wakeboards in Jakarta as seen from the physical profile tested and measured in anthropometry and biomotor components.

Water skiing is a sport of established popularity with an estimated 8.4 million participants (Bray-Miners et al., 2013, 2015; Hostetler et al., 2005; Jung et al., 2021). Wakeboarding, a relatively new water sport combining water skiing and 
snow boarding, has experienced a $49 \%$ increase in participation during the past 5 years to an estimated 3.4 million participants (Hostetler et al., 2005).

The International Waterski \& Wakeboard Federation (IWWF) is the world governing body for towed water sports and has 91 affiliated national federations. The IWWF's competitive and recreational towed water sport divisions include Tournament (3-event water skiing), Wakeboard, Barefoot, Show Skiing, Cable Wakeboard, Cable Ski, Ski Racing, and Disabled Skiing(Jung et al., 2021). Water skiing involves two distinct activities: (1) bringing the water ski to plane and (2) performing cutting maneuvers often across a boat wake. Each activity produces different loading profiles that are transmitted to the bootbinding system (Suderman et al., 2020).

The element of good physical condition is one of the supporting achievements of a sport but not only that basic engineering skills become a supporting role for the achievement of an athlete's achievements. Mastery of good basic techniques and good physical condition for athletes must certainly be considered by a coach to deliver his athletes at the highest achievements.

Researchers raise research used is descriptive quantitative with survey methods, which is a study that collects data obtained from data collection in the form of tests and measurements. The free variables in this study are anthropometric and biomotor profiles and the bound variables are water skiers and wakeboard athletes of DKI Jakarta Province. Data analysis or data classification is an important step in research.

\section{METHODS}

The research method used is Quantitative Descriptive, which is a study that collects data obtained from survey results obtained data from tests and measurements, consisting of anthropometric tests consisting of height and weight while biomotor components consist of the explosiveness of leg muscles, abdominal muscle strength, endurance, agility, and speed.

\section{Participants}

The sample in this study was the male athlete of Water Ski Athletes and Wakeboard DKI Jakarta Province as many as 25 people. This research was conducted on August 1, 2021, at Lake Sunter street Danau Permai Raya No.01 ward Sunter Jaya districts Tanjung Priok North Jakarta.

\section{Sampling Procedures}

The sampling procedure in this study used purposive sampling, considering the characteristics of the sample following the length of exercise of at least one year or more joined in Water Ski and Wakeboard DKI Jakarta province.

\section{Materials and Apparatus}

Data collection techniques use tests and measurements:(i) weight scales to measure weight. Brightly measured by a weight gauge with a unit of a kilogram; (ii) test of physical condition; Flexibility using sit and reach test; core stability is athletes do with 12 levels with perfect attitude, level 1 to level 12 where levels 1 and 12 for 30 seconds, level 2 to level 10 for 15 seconds, test set-ups and push-ups athletes do tests for 1 minute, explosive limbs do standing long jump tests, and endurance perform Multi-Stage Fitness Test (MFT).

\section{Procedures}

The sample in this study was the male athlete of Water Ski Athletes and Wakeboard DKI Jakarta Province as many as 25 people. This research was conducted on August 1, 2021, at Lake Sunter street 
Danau Permai Raya No.01 ward Sunter Jaya districts Tanjung Priok North Jakarta.

\section{Design or Data Analysis}

The data analysis in this study used descriptive analysis of percentages. After the data is obtained, then continued by analyzing the data to conclude this study using quantitative descriptive analysis techniques, overall data analysis using Microsoft excel 2019.

\section{RESULTS}

Based on the results of descriptive analysis of frequencies about anthropometric tests and measurements and physical conditions consisting of total numbers, average values, and standard deviations can be seen in the following table:

Tabel 1. Descriptive analysis results of the total number, average value, and anthropometric deviation standards

\begin{tabular}{lrrlr}
\hline \multirow{2}{*}{ Variable } & \multicolumn{4}{c}{ Anthropometry } \\
\cline { 2 - 5 } & N & Sum & Mean & SD \\
\hline Weigh & 25 & 1649.9 & 65.96 & 5.34 \\
\hline Heigth & 25 & 4300.7 & 172.03 & 4.95 \\
\hline
\end{tabular}

Based on table 1 it can be described that anthropometry for indicators: (i) the weight of 25 athletes obtained a total amount of $1648.9 \mathrm{Kg}$, an average value of $65.96 \mathrm{Kg}$; and a standard deviation of 5.39; and (ii) the height indicator obtained a total amount of $4300.7 \mathrm{~kg}$, an average value of 172.03, and a standard deviation of 4.95 . Furthermore, the analysis of physical condition consists of flexibility, limb explosiveness, and abdominal muscle strength tests, the results of the data analysis can be seen in the following table:
Tabel 2. Descriptive analysis results of the total number, average value, and standard deviation of physical condition

\begin{tabular}{lcccc}
\hline \multirow{2}{*}{ Variable } & \multicolumn{4}{c}{ Physical condition } \\
\cline { 2 - 5 } & N & Sum & Mean & SD \\
\hline Flexibility & 25 & 833.5 & 33.34 & 5.31 \\
\hline $\begin{array}{l}\text { Core } \\
\text { stability }\end{array}$ & 25 & 168 & 6.72 & 2.01 \\
\hline Sit-up & 25 & 899 & 35.56 & 10.05 \\
\hline Push-up & 25 & 706 & 28.24 & 6.48 \\
\hline $\begin{array}{l}\text { Grip } \\
\text { strength }\end{array}$ & 25 & 1024 & 40.98 & 8.17 \\
\hline $\begin{array}{l}\text { Limb } \\
\text { explosive } \\
\text { power }\end{array}$ & 25 & 53.35 & 2.13 & 0.39 \\
\hline Endurance & 25 & 676.1 & 27.04 & 3.55 \\
\hline
\end{tabular}

Based on table 1 on the profile of the dominant physical condition of Water Ski athletes and Wakeboard DKI Jakarta Province the physical condition of 25 samples was tested: (i) flexibility was obtained a total amount of $833.5 \mathrm{~cm}$, an average value of $33.34 \mathrm{~cm}$, and a standard deviation of 5.31 ; (ii) core stability obtained a total amount of 168, an average value of 6.72, and a standard deviation of 2.01; (iii) sit-ups were obtained a total amount of 899 , an average value of 35.56 , and a standard deviation of 10.05; (iv) push-ups were obtained a total amount of 706 , an average value of 28.24 , and a standard deviation of 6.48 ; (v) the strength of the gang obtained a total amount of 1024 , the average value of 40.98 , and the standard deviation of 8.17 ; (vi) the explosive power of the leg muscles is obtained a total amount of 53.35, an average value of $2.13 \mathrm{~cm}$, and a standard deviation of 0.39; and (vii) endurance obtained a total amount of 676.1, an average value of 27.04 , and a standard deviation of 3.55. The result of a descriptive analysis of the anthropometric and biomotor profiles and their bound variables are water Ski and wakeboard athletes of DKI Jakarta Province, as the basis for compiling the exercise program. 


\section{DISCUSSION}

In this study, the researcher raised the research used is quantitative descriptive with descriptive methods, which is a study that collects data obtained from the collection of data in the form of tests and measurements. The free variables in this study are anthropometric profiles and physical conditions and the bound variables are Water Skiers and Wakeboard Athletes of DKI Jakarta Province.

The results of previous research on water skiing and waterboarding were carried out by Hostetler Data were collected for 517 individuals with water skiing related injuries and 95 individuals with wakeboarding-related injuries. These injuries represent an estimated 23460 water skiing and 4810 wakeboarding related injuries treated in US emergency departments in 2001 to 2003 (Hostetler et al., 2005). Three-event water skiing is widely considered to be the most demanding discipline in towed watersports. Various fitness components such as muscular strength and endurance,dynamic balance, and coordination are required to succeed in waterskiing competition (Jung et al., 2021).

This study analyzed the impact of ski design and skier ability on dynamic performance while slalom water skiing. The subject pool utilized in this study as limited to advanced skiers. The experimental procedure was controlled where possible to reduce the impact of weather, fatigue and inconsistent subject activities (Bray-Miners et al., 2015). Furthermore, the analysis resulted in the identification of two themes: the content of the cable wakeboarding information and procedures, and the city beach community. Overall, the participants' sense-making of risk in adventure recreation was explored and found to be framed by local attachment and a combination of individualistic and collectivistic perspectives of risk (Wall, 2021).

Practising slalom water-skiing in sitting position by people experiencing paraplegia leads to a decrease in the maximum HGS of the dominant hand, the percentage decrease may be in relation to competitive level and physical fitness of the skiers (Wall, 2021).

The quality of human resources must be improved continuously by science and technology as well as national developments. Athlete Breeding is an important stage in the coaching of water Ski and wakeboard sports achievements which is the foundation of the building of achievement coaching systems in the sport of Water Ski and Wakeboard. The achievement coaching system aims to achieve a high level of achievement then a good nursery system is needed.

Maximum achievement achieved by athletes is influenced by several factors, including external factors and internal factors. External factors are factors that affect the achievement of athletes who come from outside the athlete such as coaches, training methods, and the environment. While internal factors are factors that affect the achievement of athletes who come from within the athlete itself.

Physical condition is one of the components of internal factors in achieving optimal achievement, so it is very important to know how the level of the physical condition of an athlete. When athletes are in preparation physically and mentally less than the feeling of athletes before competing will feel anxious. This anxiety will interfere with the performance of athletes during competition and hinder the achievement of athletes $(\mathrm{H}$. Indrawira, U. Maslikah, G. Jariono, H. Nugroho, 2021; Jariono et al., 2020; Ruslan, 2011).

The quest for the achievement of Water Ski and Wakeboard achievements is 
no different from the achievement of sports achievements in general, as outlined above. Of the many elements for the achievement of sports achievements, the achievements of Water Ski and Wakeboard can be concluded as the result of training that includes aspects (i) The physical aspects of the dominant Water Ski and Wakeboard sports are adapted to the energy system that works in each category, for the category of anaerobic ability countering greater than aerobics. Therefore, the components or physical that are expected to be owned in the counter category are speed, reaction, agility, coordination, strength, defense and supported by components of balance, flexibility, and accuracy; (ii) The dominant technical aspects or basic skills of Water Ski and Wakeboard athletes; (iii) The tactical and strategic aspect is the athlete's ability to win matches with the help of a coach. The coach plays an important role in this because a good athlete and assisted by the right-field analysis skills by the right coach will produce the expected winning strategy; (iv) Spiritual mental aspects are needed in martial arts, particularly Water Ski and Wakeboard, but are different in each category. For Water Ski and Wakeboard, the mental aspects needed are confidence, aggressiveness, self-perception, and achievement motives.

Maximum mastery of skills is the embodiment of body mechanics that affect the efficiency of the use of power in support to improve the achievements of sportsmen, coaches must know in depth the characteristics of the skills of the sport by paying attention to the components of physical condition (T. Bompa \& Buzzichelli, 2015).

Physical condition is a complete unity of components that cannot be separated just like that, both improvement and maintenance, meaning that in the effort to improve physical condition, all components must be developed, although done with a priority system according to the circumstances or status of each component and for what purposes or status is needed (Suharjana, 2015).

Flexibility is one of the components of physical condition, which is categorized also as a component of basic physical conditions. Referred to as a basic physical component because the flexibility stands alone, not affected by other components of physical condition(Aras et al., 2017; Giandika et al., 2016).

Major stability also plays an important role in the performance of motion in sports dispensation as well as in daily life (Aytar et al., 2012; Firdauz \& Setijono, Hari., 2017; Uzizatun Maslikah et al., 2021). Balance has a variety of very important factors, so the balance factor here plays a very large role in children in doing sports activities and in everyday life because the balance will be one of the most important parts of human life in doing sports activities (Aytar et al., 2012; Leong et al., 2011; Pedlar et al., 2018; Ricotti, 2011).

Explosive power can be expressed as an explosive force and much needed by sports that require rapid and strong muscle contraction, these two elements are mutually influential (Cormie et al., 2011; Nugroho et al., 2021; Suharjana et al., 2020). The strength of a muscle is determined primarily by its size, so the strength of a muscle can be affected by testosterone levels in its body as well as from a work exercise program that will increase the size of the muscle (Bacurau et al., 2009; Chan, 2012; Firdauz \& Setijono, Hari., 2017; Voet et al., 2019).

Muscle endurance is the ability of muscles to generate force at specific times and speeds. Muscle strength and muscle endurance will decrease in the aging process with muscle endurance decreased greater than muscle strength (Aagaard \& 
Andersen, 2010; Häkkinen et al., 2003; Stöggl \& Sperlich, 2014).

The results of this study showed that the average height in the ideal category and physical condition as a basis for the preparation of the exercise program, so that the exercise program is by the expected joint achievements.

\section{CONCLUSION}

The results of this study can be concluded: anthropometry and physical condition is one of the important factors in determining the achievement of athletes, without exception in Water Ski and Wakeboard Athletes of DKI Jakarta province.

\section{ACKNOWLEDGEMENT}

Thank you to the Faculty of Sports Science, Universitas Negeri Jakarta who has fully facilitated to researchers to research young lecturer research grants in the fiscal year 2021. Furthermore, the researchers thanked the team and administrators, coaches and water skiers, and wakeboard athletes of DKI Jakarta Province to help the research process until the end of the study.

\section{REFERENCES}

Aagaard, P., \& Andersen, J. L. (2010). Effects of strength training on endurance capacity in top-level endurance athletes. In Scandinavian Journal of Medicine and Science in Sports. https://doi.org/10.1111/j.16000838.2010.01197.x

Aras, D., Arsyad, A., \& Hasbiah, N. (2017). Hubungan Antara Fleksibilitas Dan Kekuatan Otot Lengan Dengan Kecepatan Renang. Media Kesehatan Masyarakat Indonesia. https://doi.org/10.30597/mkmi.v13i4.31 60

Aytar, A., Pekyavas, N. O., Ergun, N., \&
Karatas, M. (2012). Is there a relationship between core stability, balance and strength in amputee soccer players? A pilot study. Prosthetics and Orthotics International.

https://doi.org/10.1177/03093646124458 36

Bacurau, R. F. P., De Assis Monteiro, G., Ugrinowitsch, C., Tricoli, V., Cabral, L. F., \& Aoki, M. S. (2009). Acute effect of a ballistic and a static stretching exercise bout on flexibility and maximal strength. Journal of Strength and Conditioning Research, 23(1), 304-308. https://doi.org/10.1519/JSC.0b013e3181 874d55

Bompa, T., \& Buzzichelli, C. (2015). Periodization Training for Sports-3rd Edition. https://books.google.com/books?id=Zb7 GoAEACAAJ\&pgis $=1$

Bompa, T. O., \& Buzzichelli, C. (2018). Periodization-6th Edition: Theory and Methodology of Training. In Human Kinetics.

Bray-Miners, J., John Runciman, R., \& Monteith, G. (2013). Water skiing biomechanics: A study of advanced skiers. Proceedings of the Institution of Mechanical Engineers, Part P: Journal of Sports Engineering and Technology, 227(2), 137-146. https://doi.org/10.1177/17543371124446 88

Bray-Miners, J., Runciman, R. J., Monteith, G., \& Groendyk, N. (2015). Biomechanics of slalom water skiing. Proceedings of the Institution of Mechanical Engineers, Part P: Journal of Sports Engineering and Technology, 229(1), 47-57. https://doi.org/10.1177/17543371145475 55

Chan, F. (2012). Strength Training (Latihan Kekuatan). Cerdas Sifa.

Cormie, P., McGuigan, M. R., \& Newton, R. U. (2011). Developing Maximal Neuromuscular Power. Sports Medicine. https://doi.org/10.2165/11538500000000000-00000

Fachrezzy, F., Jariono, G., Maslikah, U., \& Nugroho, H. (2020). Functional Exercise Model for Weight Loss in Sports Science Faculty Students. International Summit 
on Science Technology and Humanity (ISETH) 2020, 159-165.

Firdauz, N. W. R., \& Setijono, Hari., M. (2017). The Effect of Core Stability Dynamic and Medicine Ball Training to Enhancement Leg Muscle Strength, Abdominal Muscle Strength, and Balance. Journal of Sport Science and Education (JOSSAE), 2, 65-70.

Giandika, M. D., Kusmaedi, N., \& Rusdiana, A. (2016). Hubungan Kemampuan Waktu Reaksi dan Fleksibilitas Atlet UKM Taekwondo UPI dengan Hasil Tendangan Dollyo-Chagi. Jurnal Terapan Ilmu Keolahragaan, 1(1), 12. https://doi.org/10.17509/jtikor.v1i1.1546

H. Indrawira, U. Maslikah, G. Jariono, H. Nugroho, I. H. (2021). Pelatihan dan Penyusunan Latihan Fisik Pada Anggota Komando Strategis Angkatan Darat ( KOSTRAD ). JURNAL ALTIFANI: Penelitian Dan Pengabdian Kepada Masyarakat, 1(1), 27-34. https://doi.org/10.25008/altifani.v1i1.11 5

Häkkinen, K., Alen, M., Kraemer, W. J., Gorostiaga, E., Izquierdo, M., Rusko, H., Mikkola, J., Häkkinen, A., Valkeinen, H., Kaarakainen, E., Romu, S., Erola, V., Ahtiainen, J., \& Paavolainen, L. (2003). Neuromuscular adaptations during concurrent strength and endurance training versus strength training. European Journal of Applied Physiology. https://doi.org/10.1007/s00421-0020751-9

Hermawan, I., Indrawira, H., Maslikah, U., Jariono, G., \& Nugroho, H. (2021). Pelatihan dan Penyusunan Latihan Fisik Pada Anggota Komando Strategis Angkatan Darat ( KOSTRAD ). JURNAL ALTIFANI : Penelitian Dan Pengabdian Kepada Masyarakat, 1(1), 27-34. https://doi.org/10.25008/altifani.v1i1.11 5

Hostetler, S. G., Hostetler, T. L., Smith, G. A., \& Xiang, H. (2005). Characteristics of water skiing-related and wakeboardingrelated injuries treated in emergency departments in the United States, 20012003. American Journal of Sports Medicine, 33(7), 1065-1070. https://doi.org/10.1177/03635465042717
48

Jariono, G., Nursubekti, N., Indarto, P., Hendarto, S., Nugroho, H., \& Fachrezy, F. (2020). Analisis kondisi fisik menggunakan software Kinovea pada atlet taekwondo Dojang Mahameru Surakarta. Transformasi: Jurnal Pengabdian Masyarakat. https://doi.org/10.20414/transformasi.v1 $6 i 2.2635$

Jariono, G., \& Subekti, N. (2020). Sports Motivation Survey And Physical Activity Students Of Sport Education Teacher Training And Education Faculty FKIP Muhammadiyah University Surakarta. Kinestetik: Jurnal Ilmiah Pendidikan Jasmani. https://doi.org/10.33369/jk.v4i2.12449

Jung, H. C., Straltsova, H., Woodgate, M. A., Kim, K. M., Lee, J. M., Lee, J. H., \& Gann, J. J. (2021). Water ski injuries and chronic pain in collegiate athletes. International Journal of Environmental Research and Public Health, 18(8), 1-13. https://doi.org/10.3390/ijerph18083939

Leong, H. T., Fu, S. N., Ng, G. Y. F., \& Tsang, W. W. N. (2011). Low-level Taekwondo practitioners have better somatosensory organisation in standing balance than sedentary people. European Journal of Applied Physiology. https://doi.org/10.1007/s00421-0101798-7

Nugroho, H., Gontara, S. Y., Angga, P. D., Jariono, G., \& Maghribi, I. L. (2021). Quality Of Physical Condition Of Youth Pencak Silat Athletes Reviewed From Speed , Power. Kinestetik : Jurnal Ilmiah Pendidikan Jasmani, 5(1), 154-162. https://ejournal.unib.ac.id/index.php/kine stetik/article/view/14376

Ohayon, M. M. (2005). Relationship between chronic painful physical condition and insomnia. Journal of Psychiatric Research.

https://doi.org/10.1016/j.jpsychires.2004 .07 .001

Pedlar, C. R., Brugnara, C., Bruinvels, G., \& Burden, R. (2018). Iron balance and iron supplementation for the female athlete: A practical approach. In European Journal of Sport Science. https://doi.org/10.1080/17461391.2017.1 
416178

Ricotti, L. (2011). Static and dynamic balance in young athletes. In Journal of Human Sport and Exercise. https://doi.org/10.4100/jhse.2011.64.05

Ruslan. (2011). Meningkatkan Kondisi Fisik Atlet Pusat Pendidikan. Ilara.

Stöggl, T., \& Sperlich, B. (2014). Polarized training has greater impact on key endurance variables than threshold, high intensity, or high volume training. Frontiers in Physiology. https://doi.org/10.3389/fphys.2014.0003 3

Suderman, B. L., Sklar, A., Stepan, L. L., \& Scher, I. S. (2020). Water Ski Binding Release Characteristics in Forward Lean. Proceedings, $49(1), \quad 76$. https://doi.org/10.3390/proceedings2020 049076

Suharjana, -. (2015). Latihan Beban: Sebuah Metode Latihan Kekuatan. MEDIKORA. https://doi.org/10.21831/medikora.v0i1.4 719

Suharjana, Priyanto, E., \& Ndayisenga, J. (2020). Contribution of leg power, arm power, stomach muscle power, and back muscle power on jumping services. International Journal of Human Movement and Sports Sciences. https://doi.org/10.13189/saj.2020.08051 2

UU No 3 Tahun 2005. (2005). Undang-Undang Republik Indonesia Nomor 3 Tahun 2005 Tentang Sistem Keolahragaan Nasional Dengan. Presiden RI, 1, 1-53.

UU RI. (2005). Undang-Undang No. 3 Tahun 2005 tentang Sistem Keolahragaan Nasional. In Undang-Undang No. 3 Tahun 2005 tentang Sistem Keolahragaan Nasional.

Uzizatun Maslikah, Fahmy Fachrezzy, \& Haris Nugroho. (2021). Contribution core stability and strength to the performance athlete Slalom Number Water Ski in terms of gender Characteristics. International Journal of Science, Technology \& Management, 2(3), 9081006. https://doi.org/10.46729/ijstm.v2i3.228

Voet, N. B. M., van der Kooi, E. L., van Engelen, B. G. M., \& Geurts, A. C. H. (2019). Strength training and aerobic exercise training for muscle disease. In Cochrane Database of Systematic Reviews. https://doi.org/10.1002/14651858.CD00 3907.pub5

Wall, E. (2021). Cable Wakeboarding for the First Time: How Young People Make Sense of Risk in Adventure Recreation. Young, 29(3), 305-320. https://doi.org/10.1177/11033088209450 99 